\title{
Mikołaj Jalinik
}

Białystok University of Technology in Hajnówka

e-mail: jalinik@op.pl

\section{TOURIST TRAFFIC IN THE BIALOWIEŻA FOREST IN THE LIGHT OF RESEARCH}

\section{RUCH TURYSTYCZNY NA OBSZARZE PUSZCZY BIALOWIESKIEJ W ŚWIETLE BADAŃ}

DOI: $10.15611 /$ pn.2017.473.22

\begin{abstract}
Summary: Tourist traffic is a socio-economic phenomenon and it has its specific features. The increase in the pace of life has its consequences mainly in the ways of organizing free time, and it has to do with a good rest. Many definitions and classifications of tourist traffic can be found in the subject literature. The intensity of tourist traffic varies in different seasons of the year. It should be noted that in addition to the proximity of the place of residence, qualities of the natural environment have been the main motive to come to the Białowieża Forest. This has been due to such factors as the attractiveness of the area, geographic location, international events and historical conditions. Therefore, the stay in the area of the Białowieża Forest focuses mainly on its exploration, experiences, leisure and entertainment. Studies have shown that there is a clear trend towards shortening the length of stay, and a few weeks' holiday trips to one place have a tendency virtually to disappear. At the same time, weekend trips in summer and winter are growing in popularity.
\end{abstract}

Keywords: tourist traffic, Białowieża Forest, attractions and tourist attractiveness.

Streszczenie: Ruch turystyczny jest zjawiskiem o charakterze społeczno-ekonomicznym i posiada swoje specyficzne cechy. Wzrost tempa życia ma konsekwencje głównie w organizacji czasu wolnego, polegające na dobrym wypoczynku. W literaturze przedmiotu można znaleźć wiele definicji i klasyfikacji ruchu turystycznego. Natężenie ruchu turystycznego w poszczególnych sezonach jest zróżnicowane. Należy stwierdzić, że obok bliskości miejsca zamieszkania, walory środowiska przyrodniczego były głównym motywem przyjazdu do Puszczy Białowieskiej. Wpłynęły na to takie czynniki jak: atrakcyjność obszaru, położenie geograficzne, imprezy międzynarodowe i uwarunkowania historyczne. Stąd też pobyt na obszarze Puszczy Białowieskiej koncentrował się głównie na poznaniu, przeżyciach, wypoczynku i rozrywkach. Badania wykazały, że rysuje się wyraźna tendencja do skracania okresu pobytu, praktycznie zanikają kilkutygodniowe wyjazdy wypoczynkowe w jedno miejsce, a zwiększa się popularność krótkich wyjazdów weekendowych letnich i zimowych.

Słowa kluczowe: ruch turystyczny, Puszcza Białowieska, atrakcje i atrakcyjność turystyczna. 


\section{Introduction}

The region of the Białowieża Forest can be classified as one of the most attractive and most valuable places in Europe, due to its unique nature, multiculturalism and multinationalism. [Raport $\mathrm{z}$ badania... 2014] There have been published dozens of articles on the Białowieza Forest in magazines and compact positions, but tourism and its visitors, who most often and most willingly visit the Białowieża Forest, have never been presented in a detailed way.

The author of the study conducted his research in the field of tourism using the questionnaire technique among the owners of hotels and restaurants, as well as visitors to Białowieża municipality.

The attractiveness of every area is based primarily on its climate, unpolluted environment, varied configuration of its terrain and existing attractions. Although visitors rarely directly refer to the issues of environmental protection, natural and cultural values are an important component of choice of a travel destination. In a process of selecting a tourist destination and recreation areas with relatively higher share of values and tourist attractions are usually looked for. However, not only forest areas or surface water, but also tourist infrastructure can determine the possibilities of tourism development of the area. The study applies only to the area of the Białowieża Forest within the borders of Poland.

The aim of the study is to analyze and evaluate the tourist traffic in the area of the Białowieża Forest based on surveys that were carried out in the months of June and July 2016. There are often expressed opinions that tourists come to Białowieża for a longer holiday or they are exclusively engaged in scientific research. Therefore, the author decided to investigate this kind of suppositions using survey results to confirm from which places and localities and for which period tourists come, and what is the main reason of their arrival. Staying of visitors in accommodation and catering facilities indicates a high probability of recreation in the area of the Białowieża Forest.

Values of the Białowieża Forest should encourage tourists to stay longer, but still poorly developed tourist infrastructure is not conducive to the arrival of larger groups of visitors.

\section{Tourist traffic in view of various authors}

Tourism is a complex phenomenon and it can be examined based on different criteria. The most commonly used criterion of division of tourist traffic is the duration of the stay. Domestic tourists have dominated among the visitors of the Białowieża Forest for many years. They are mostly the residents of the following voivodships: Podlasie, Mazowsze and Lublin, and to a lesser extent, the inhabitants of Silesia, Pomerania and Podkarpacie, but it can be also said that the tourist traffic is mostly concentrated in Białowieża. 
Currently tourist traffic takes many forms, and its classification constitutes a very complex and multi-level issue. According to the International Academy of Tourism in Monte Carlo these are journeys undertaken for pleasure, relaxation or treatment - on foot or by any means of transport. Their scope does not include travel for work purposes or for changing the place of residence (or the settlement in a certain place). [Gaworecki 2010, p.17] In turn, A.S. Kornak believes that it is a social phenomenon manifested by spatial movement of people to other areas and tourist destinations. [Kornak 1979, p.47] It includes travelers motivated by various socio-cultural and professional objectives, which are to be achieved after a temporary and voluntary leaving the place of the habitual residence in the country or abroad. [Gaworecki 2010, p.17] Travelling persons generate demand for goods and services, both during their travel as well as during their stay outside the place of their permanent residence. Therefore, tourist traffic causes specific economic and social effects, the scale of which is increasing together with its scale. [Ekonomia turystyki 2007, p.24] French researcher M. Boyer, emphasizing the social nature of tourism, defines tourist traffic as travelling for leisure, and for cognitive, cultural and educational purposes. [Gaworecki 2010, p.17] Tourist traffic is defined as a form of externalization of the specific social need, which constitutes the tourist demand. From an economic point of view, tourism generates a definite demand for goods and services, manifested both during travel and the stay outside the place of permanent residence. [Łobożewicz 1997, p.41] According to A. Kowalczyk, tourist traffic is the spatial movement of people involving the voluntary and temporary change of a place of residence, the environment and the rhythm of life. [Kowalczyk 2001, p.7] Overall, it should be noted that tourist traffic is a narrower concept than tourism, because it indicates the specific movement of people for tourist purposes. [Turystyka 2007, p.13] It can be argued that each of these definitions corresponds to the essence and importance of tourist traffic, but the definition of M. Boyer is in my opinion the most suitable.

\section{The area and research methodology}

The Białowieża Forest is a vast forest complex, which is located on both sides of Polish and Belarus border and it is a remnant of four ancient forests, namely Białowieska, Ladzka, Świsłocka and Szereszewska.

The Białowieża Forest is a forest complex with an area of approximately 150 thousand hectares, divided after World War II by the state border. The western part is in the Podlasie Voivodeship (62.5 hectares), and the eastern part is in Belarus (87.5 thousand hectares). The forest is in the basin of two rivers, the Narewka and Leśna. [Kozieł 2010. pp.271-284] In 1989 it was recognized as a protected landscape area, which covers 3200 hectares. In the Białowieża Forest survived the last fragments of original forests in the European lowlands, and in them the largest European animal - the European bison. Generally, it can be said that this place is a habitat for various species of flora and fauna. 
A special feature of each tourist product is the impossibility of its storage, even though its provision may be booked (but also in a specific place and time), and it is both produced and consumed. [Ekonomia turystyki 2007, pp.107-110] The most environmentally valuable part of the forest is protected within the boundaries of Białowieża National Park and 20 nature reserves. European and world literature on the quality of products and services in tourism is very rich. The works of AlbaceteSáez and others [2007, pp.45-65] and Khan [2003, pp.109-124] refer to the subject mentioned above. Due to its unique natural values, the entire Polish part of the Białowieża Forest was recognized as a World Natural Reserve by UNESCO in 2006. [Chocian, Kotowska 2008, p.21]

A characteristic feature of the Białowieża Forest complex is the presence of almost all forms of legal protection of nature (connected by ecological corridors), such as:

- national park,

- areas of Nature 2000 network,

- nature reserves,

- areas of protected landscape,

- monuments of nature,

- ecological areas. [Botomiuk, Jakimiuk 2006, p.20]

The study was conducted in accommodation establishments operating in the municipality of Białowieża, which is located entirely in the Białowieża Forest. The selection of the study area was intentional. The list of objects and their localization was obtained in the commune office in Białowieża. According to the data obtained there were operating 77 accommodation facilities in the study area in 2016 (hotels, boarding houses, agritourism farms, private lodgings, guesthouses, campings).

The study was carried out among the owners of accommodation facilities and holiday service recipients, using the method of a diagnostic survey, including a questionnaire technique. 80 research tools were directed to the owners of accommodation facilities and 90 of them were directed to service recipients. The surveys contained respectively 32 questions (the owners of the facilities) and 36 questions (service recipients) of a closed and open type. A request for answering the survey was directed to all accommodation facilities owners and service recipients staying to rest. Among the pollsters eight owners of facilities and ten service recipients did not give their replies.

The research survey questions were related to the reasons for the selection of Białowieża and the Białowieża Forest for visiting and spending leisure time, the purpose of coming to Białowieża, the age and sex of visitors, what led people to choose this region and how often they visit the Białowieża Forest, the place of residence, education level of visitors, interests, the knowledge of foreign languages, countries foreign visitors came from, the evaluation of tourist and recreational infrastructure, the time of arrival, the expectations of tourists while in the area of the Białowieża Forest, the period of staying in the area of the forest, and positive as well as negative assessment of the leisure time in Białowieża and the Białowieża Forest. 
Based on the research data it has been indicated how attractive Białowieża and the Białowieża Forest are and how often they are visited, as well as what period guests tend to stay in the area and for how long, and what is the reason for their arrival.

\section{The analysis of the research results}

Forest areas are an important factor in the attractiveness of the area, and with the efficient and effective local government policy they can constitute a significant element in the development of tourism. The development of tourism in forest areas is one of the most important forms of uses of their non-productive function. As it is stated by Gaworecki [Gaworecki 2010, p.376], forest areas are a desirable area for practicing various types and forms of tourism. It is important for tourists visiting forest areas to find not only natural values there, but also historical and cultural, and above all anthropogenic attractions. Forest areas play an increasingly important role as sites of tourist-recreation, especially near large urban areas, where their residents willingly want to take advantage of the pristine environment and be away from the city noise and pollution. The Białowieża Forest is undoubtedly such a place.

Well-organized tourist facilities cannot only create ideal conditions for relaxation, but they are also conducive to getting to know such a complex and somewhat mysterious ecosystem, which the Białowieża Forest is. However, if tourism is poorly planned and organized, this can pose a serious threat for forest areas. [Jalinik 2014, p.142] As it turns out the expectations of respondents concerning the forest areas and the use of forest resources are varied. The studies have confirmed that visitors to forest areas recognize their non-productive functions, especially in the field of tourism infrastructure, ecology, conservation and the preservation of biodiversity. Productive functions were less important for respondents, even though they took a critical stance to the "mess" in the forest (fallen trees), where not only people but also animals had some difficulty in moving.

In answer to the question concerning the association of the forest, $79.5 \%$ of respondents said that they associated it with a bison and the area of woodland, $13.5 \%$ of them connected it with unpolluted environment, and $7 \%$ with a regional cuisine. Then, as for the motives of the respondents for visiting the Białowieża Forest, most respondents stated that they were interested in spending their leisure time in an active way and staying for doing their scientific research (Figure 1).

Although service recipients declared a recreational stay, their average stays were still very short, as it was stated both by the owners of accommodation facilities as well as by the recipients themselves (Figure 2). It is also worth noting that the longest stays were in the months of July and August, while the shortest in winter (in December and January).

The respondents gave as a reason for their short stay the fact that there were too few tourist attractions in the area of the Białowieża Forest and the presence of mosquitoes, and the fact that there were not enough bicycle paths. In their opinion 


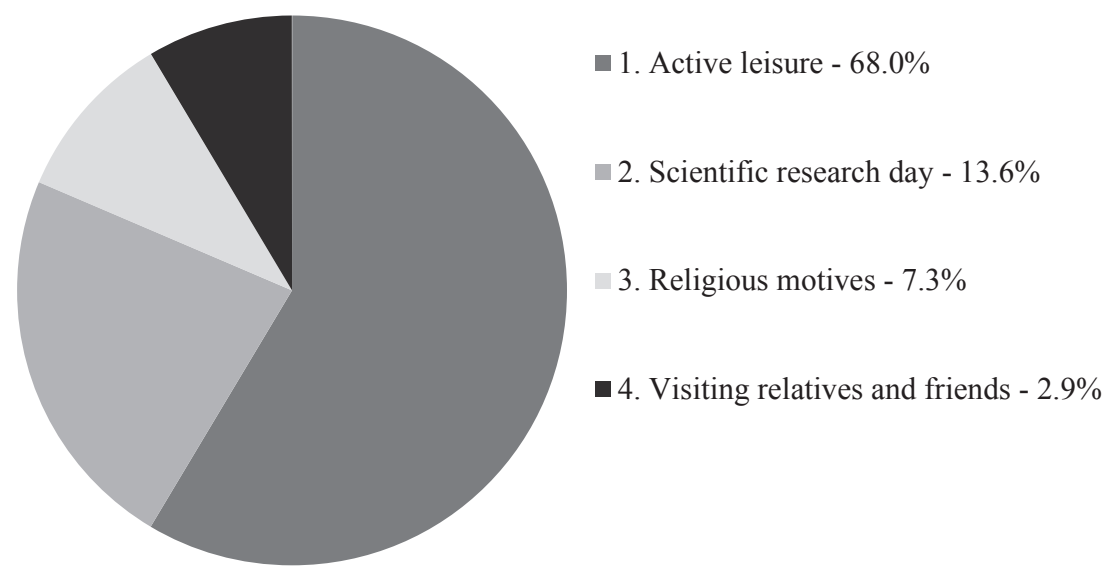

Figure 1. The Białowieża Forest arrival motives

Source: own study based on the research results.

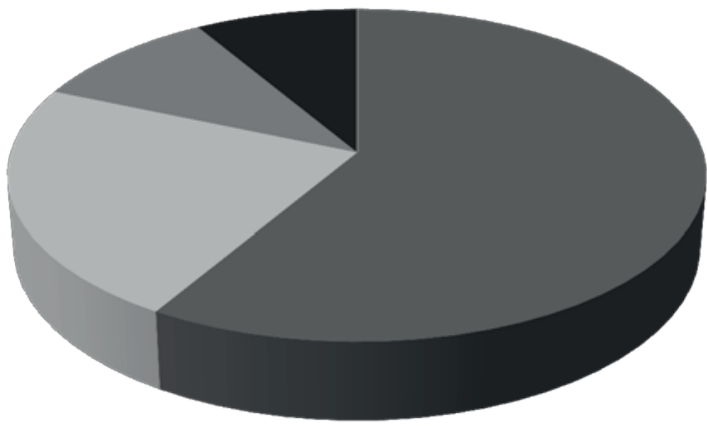

घ1. Tourist stays for not more than one week - $46.5 \%$

2. Tourist stays for two weeks - $30.6 \%$

3. Tourist stays for three weeks - $15.4 \%$

4. Tourist stays for more than three weeks $-7.5 \%$

Figure 2. Tourist stays in Białowieża commune

Source: own study based on the research results.

there was a need to develop equipment rental business (mainly of bicycles, kayaks, the equipment for Nordic walking, and winter equipment). They pointed out that there were very poor transport links (there were only some buses and the railway connection did not exist) (Figure 4). Starting journeys by train or having more bus connections certainly would revitalize tourist traffic in a significant way. Some of the respondent (14.9\%) stated that they could visit all the places in one week, and then the following days were becoming less attractive so they decided to return to the places of their residence. 


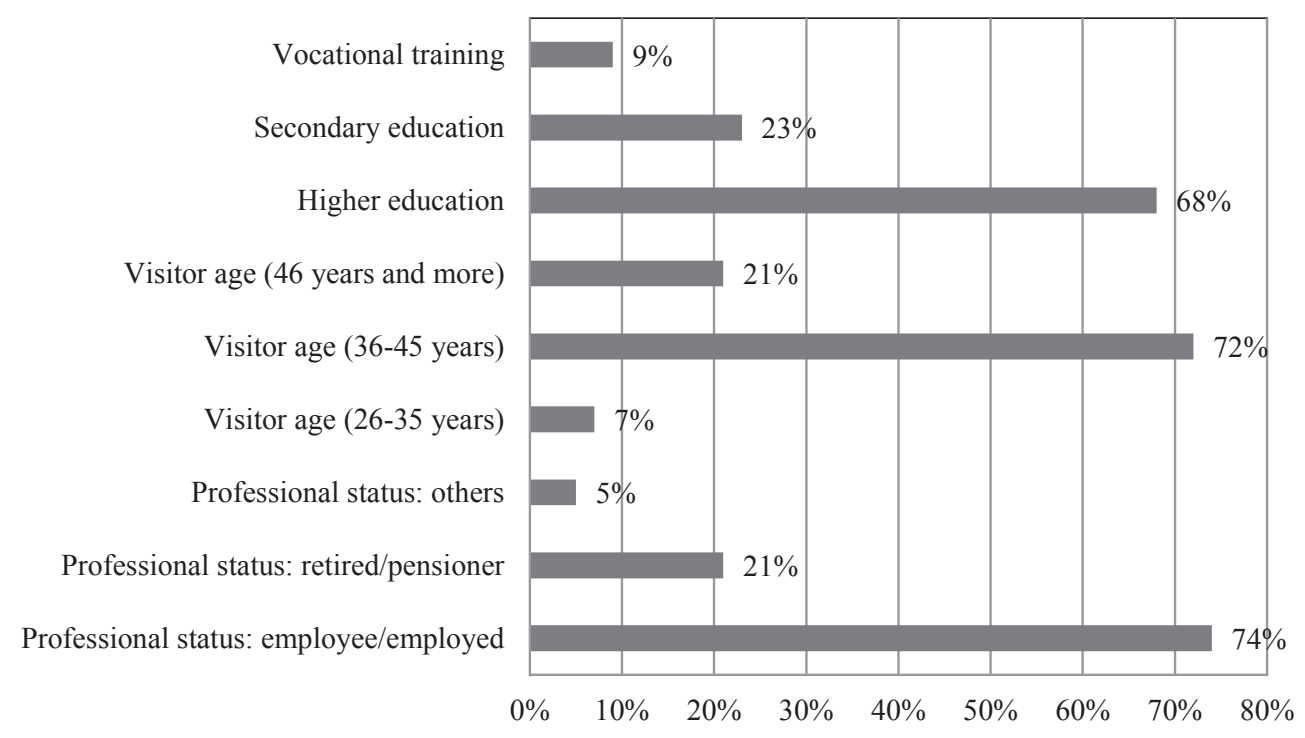

Figure 3. Characteristics of visitors to the Białowieża Forest

Source: own study based on the research results.

It should be noted, however, that in 2016 the number of tourists visiting the Białowieża Forest increased compared with the year 2015 and the other years, as it was stated by the owners of accommodation facilities. Therefore, tourist traffic increased. The reason for that was the information in the media related to the ravages of spruce bark beetle that attacked spruce trees. It simultaneously provoked the interest in the Białowieża Forest on the part of Polish residents. Another reason for that may be the terrorist attacks in several European countries in relation to which a lot of people decided not to go to these countries and ultimately some of them chose to stay in Białowieża. It is a probable reason for visiting Białowieża and the forest, even though certainly there are other reasons on the part of foreign visitors to come and stay in the region.

According to the owners of accommodation facilities in the municipality of Białowieża, the forest is mostly visited by tourists coming from the following voivodeships: Mazowsze, the region of Łódź, Wielkopolska and Silesia. These people used accommodation services at least for one week. Besides Polish residents the Białowieża Forest was also visited in larger numbers by tourists from Germany, France, Russia and Spain. Among other countries interviewers also mentioned tourists from Belarus, the United States, the Netherlands, Austria, Japan, and the United Kingdom. ${ }^{1}$ The respondents stated that, for example, Belarussians were interested mainly in shopping tourism, rather than taking a rest in the area of the Białowieża Forest.

\footnotetext{
${ }^{1}$ Data based on the research results.
} 
Most tourists visiting Białowieża and the Białowieża Forest are between 36 and 45 years old and have higher and secondary education, with employment in institutions, and manufacturing and service companies (Figure 3). Among the visitors, $64 \%$ were males and $36 \%$ were females. This shows that married couples did not predominate. They usually plan a few days' family holiday, but in this case these were mostly short "sightseeing trips".

It was emphasized by service recipients that greater and greater knowledge of foreign languages among tourist guides in Białowieża was observed. Guides most frequently communicated with tourists in English, German and Russian. 67\% of respondents answered positively to the question concerning their plans to visit the Białowieża Forest again, while $64 \%$ of them considered it attractive.

Although a significant number of respondents consider the Białowieża Forest to be attractive, another open question concerned things that discourage recipients from coming to the listed area. The answers to that question are shown in Figure 4.

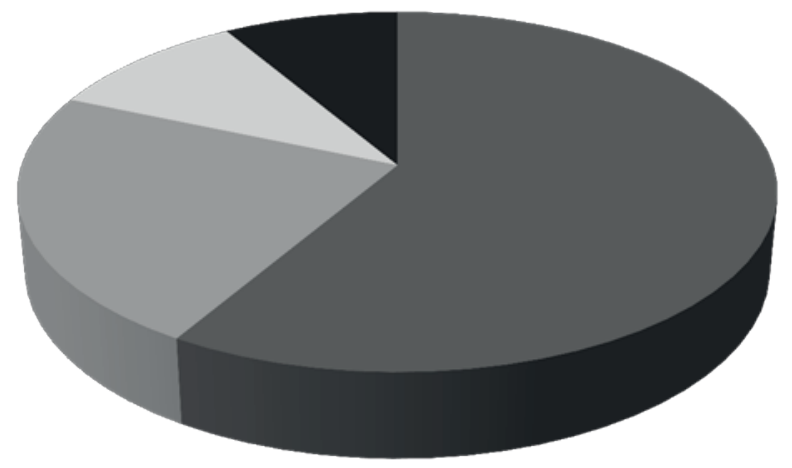

- Too few tourist attractions $36 \%$

Mosquito presence in summer and spring period $-28 \%$

Unsatisfactory transport connection - $20 \%$

- Low standard of accommodation facilities $-16 \%$

Figure 4: The evaluation of attractiveness of Białowieża and the Białowieża Forest

Source: own study based on the research results.

The majority of respondents believe that to encourage tourists to visit Białowieża and the Białowieża Forest it is necessary to increase the number of tourist attractions. There is a high probability that this would increase tourist traffic. The objects proposed by respondents to increase tourist traffic are shown in Figure 5.

These are proposals that can attract a significant number of tourists to visit the Białowieża Forest. Despite the presence of mosquitoes, a significant part of respondents considered that there were currently preventative measures against that threat and that could help. The railway connection was postulated to be restored. Then newcomers would happily come and leave without much mental stress, and even while travelling regional dishes and drinks would taste better. It was stated that consuming dishes and drinks and at the same time enjoying the landscape during the trip was a good way of spending free time. It was noted that despite the existing bus 
connection, there were still not enough rides, and in addition the vehicles were of low quality, which impaired driving comfort.

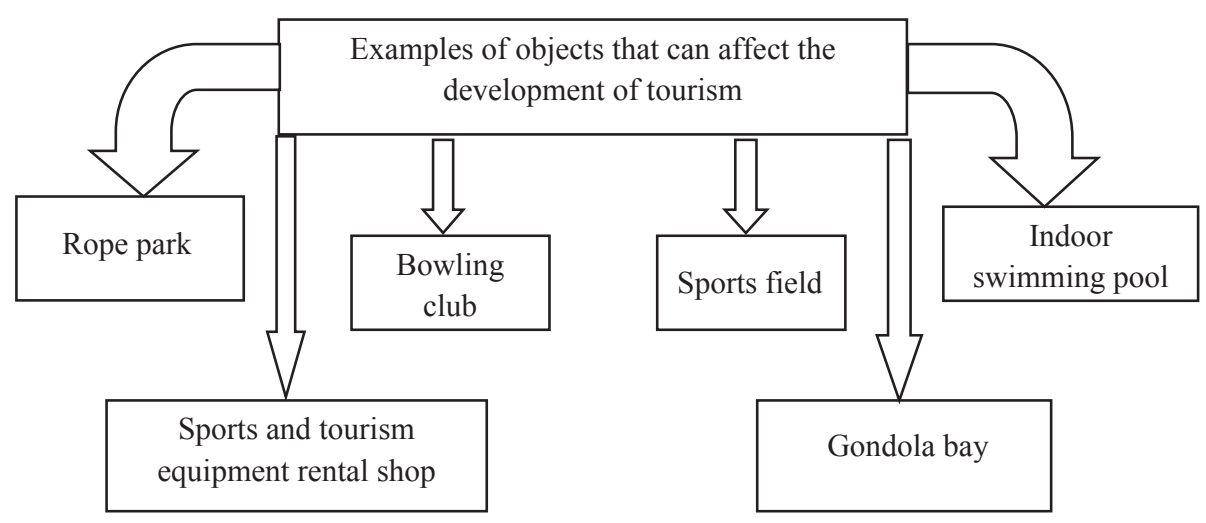

Figure 5. The proposed facilities that may cause the increase of tourist traffic

Source: own study.

Typically, every visitor tends to express his or her opinion not about what it is good, but rather he or she is more concerned what malfunctions should be improved. There are two hotel facilities in the municipality of Białowieża (one is a four-star and the other is a three-star hotel). As surveys have shown the other accommodation facilities do not please tourists in terms of comfort. Tourist traffic would certainly increase with the presence of more tourist attractions, especially during weekends, and this in turn would help to improve the budgets of municipalities of Białowieża and Hajnówka.

\section{Conclusions}

The contemporary development of civilization causes continuous growth in interest in recreation in areas of contamination-free environment. This results primarily from urbanization, changes in the professional structure of inhabitants in favor of mental work, and the general improvement of economic situation. Natural, scenic and cultural values are also a significant factor in attracting tourists to the Białowieża Forest. It should be kept in mind that forest areas are a place of rest, but they should be used in a wise way to improve physical and mental health, without violating the principles of sustainable development.

The research results have shown that in the Białowieża Forest the number of tourist attractions should be increased so that tourist traffic may grow. At the same time accommodation conditions ought to be improved and effective bus and train connections with other towns and cities should be ensured. The number of bicycle 
paths should be increased and the rental base of recreational equipment should expand (mainly bicycles, kayaks, the equipment for Nordic walking, and winter sports equipment).

With the completion of the proposed projects there is a high probability that the stays of tourists will be longer and there will be more interest in recreation in the Białowieża Forest. This will also improve the municipal budget and at the same time the financial situation of the inhabitants of the municipalities of Hajnówka and Białowieża. Special attention to very poor road infrastructure in Białowieża itself has been drawn. It causes that driving a motor vehicle is far from comfortable. The same can be said about riding a bike, and even roller skating.

\section{References}

Albacete-Sáez C.A., Fuentes-Fuentes M.M., Lloréns-Montes F.J., 2007, Service quality measurement in rural accommodation, Annals of Tourism Research, no. 34(1).

Bołtromiuk A., Jakimiuk S., 2006, Zintegrowana Strategia Rozwoju Obszarów Wiejskich Regionu Puszczy Białowieskiej, Centralna Część Krainy Żubra 2006 - 2013, EkoPress, Hajnówka.

Chocian G., Kotowska A., 2008, Strategia Rozwoju Gminy Białowieża z uwzględnieniem turystyki na lata 2007 - 2013, Ekoton, Białystok.

Ekonomika turystyki, 2007, A. Panasiuk (ed.), PWN, Warszawa.

Gaworecki W.W., 2010, Turystyka, PWN, Warszawa.

Jalinik M., 2014, Możliwości rozwoju turystyki na obszarach przyrodniczo cennych, [in:] B. Sawicki, M. Harasimiuk (eds.), Rola obszarów chronionych w rozwoju edukacji, turystyki $i$ gospodarki, Wyd. FREL, Warszawa.

Khan M., 2003, Ecoserv: Ecotourists' quality expectations, Annals of Tourism Research, Vol. 30, Issue 1, pp.109-124.

Kowalczyk A., 2001, Geografia turyzmu, PWN, Warszawa.

Kornak A.S., 1979, Ekonomika turystyki, PWN, Warszawa.

Kozieł M., 2010, Ochrona walorów przyrodniczo-krajobrazowych na pograniczu polsko-białoruskim na przykładzie Puszczy Białowieskiej, Problemy Ekologii Krajobrazu, vol. XXVI.

Łobożewicz T., 1997, Propedeutyka turystyki, Wyd. AWF w Warszawie, Warszawa.

Turystyka, 2007, W. Kurek (ed.), PWN, Warszawa.

Raport z badania ankietowego - Specyfika ruchu turystycznego w regionie Puszczy Białowieskiej, 2014, Lokalna Organizacja Turystyczna, Hajnówka. 